\title{
Sentimen Analisis Stay Home menggunakan metode klasifikasi Naive Bayes, Support Vector Machine, dan k-Nearest Neighbor
}

\author{
Ikhwanul Hakim ${ }^{1}$, Arifin Nugroho ${ }^{2}$, Sulaeman Hadi Sukmana ${ }^{3}$, Windu Gata \\ ${ }^{1}$ STMIK Nusa Mandiri \\ e-mail: 14002322@nusamandiri.ac.id \\ ${ }^{2}$ STMIK Nusa Mandiri \\ e-mail: 14002306@nusamandiri.ac.id \\ ${ }^{3}$ STMIK Nusa Mandiri \\ e-mail: sulaeman.sdu@nusamandiri.ac.id \\ ${ }^{4}$ STMIK Nusa Mandiri \\ e-mail: windu@nusamandiri.ac.id
}

\begin{abstract}
Abstrak - Dunia sedang dilanda pandemi Corona Virus, virus yang berasal dari kota Wuhan di negara Cina sebagai awal pusat dari pandemi virus tersebut. Virus tersebut menyerang pernafasan akut dan menyebar dengan cepat hampir keseluruh dunia karena proses penularannya yang relatif mudah. Pemberitaan terkait virus tersebut terjadi dengan saat masif baik dimedia nasional maupun internasional. Hampir seluruh media memberitakan tentang penyebaran virus tersebut. Salah satunya melalui media sosial, twitter adalah salah satu media sosial yang cukup banyak penggunanya dan cukup digemari. Banyak pengguna twitter membagikan informasi, mengeluarkan pendapat, maupun berbagi beberapa hal. Penelitian ini fokus pada sentimen analisis stay home pada pengguna twitter, untuk dapat melihat efek dari kebijakan tersebut terhadap kehidupan mereka. Karena hampir diseluruh negara yang terkena pandemi ini mengeluarkan kebijakan seperti itu. Data yang diperoleh akan diolah menggunakan tiga metode klasifikasi yaitu Naive Bayes (NB), Support Vector Machine $(S V M)$, dan k-Nearest Neighbor (k-NN). Dengan ketiga metode klasifikasi tersebut, akan dicari metode mana yang akan menghasilkan akurasi yang paling baik terkait dengan stay home dari tweets para penggunanya. Setelah dilakukan percobaan, algoritma Support Vector Machine + Smote mendapatkan hasil akurasi yang paling baik jika dibandingkan dengan dua algoritma lainnya. Hasil akurasi yang didapat sebesar 80,05\%.
\end{abstract}

Kata Kunci: corona virus, twitter, stay home, SVM, sentimen analisis

\begin{abstract}
The world is being hit by the Corona Virus pandemic, a virus that originated from the city of Wuhan in China as the beginning of the center of the virus pandemic. The virus attacks acute respiratory tract and spreads rapidly almost throughout the world because of the relatively easy transmission process. News related to the virus occurred at a massive time both in the national and international media. Almost all media reported about the spread of the virus. One of them is through social media, Twitter is a social media that has quite a lot of users and is quite popular. Many Twitter users share information, express opinions, and share several things. This study focuses on the sentiment analysis of stay home for Twitter users, to be able to see the effects of these policies on their lives. Because almost all countries affected by this pandemic have issued such policies. The data obtained will be processed using three classification methods, namely Naive Bayes (NB), Support Vector Machine (SVM), and k-Nearest Neighbor $(k-N N)$. With these three classification methods, we will look for which method will produce the best accuracy in terms of staying home from the tweets of its users. After an experiment, the Support Vector Machine + Smote algorithm gets the best accuracy results when compared to the other two algorithms. The accuracy results obtained are $80.05 \%$.
\end{abstract}

Keywords: corona virus, twitter, stay home, SVM, sentiment analysis

\section{PENDAHULUAN}

Corona Virus (COV) adalah salah satu patogen utama yang terutama menargetkan virus sistem pernapasan manusia. Sejak Desember 2019, total 41 kasus pneumonia yang tidak diketahui etiologi telah dikonfirmasi di kota Wuhan, Provinsi Hubei, Cina.
Sebagian besar pasien mengunjungi pasar ikan dan hewan liar setempat bulan lalu. Pada konferensi pers nasional yang diadakan hari ini, Dr JianguoXu, seorang akademisi dari Chinese Academy of Engineering, yang memimpin tim ascientific mengumumkan bahwa coronavirus jenis baru, yang secara tentatif dinamai Organisasi Kesehatan Dunia 
sebagai coronavirus baru 2019 (Lu et al., 2020).

Wabah (COV) sebelumnya termasuk sindrom pernafasan akut yang parah (SARS) - Co V dan Sindrom pernapasan Timur Tengah (MERS) - CoV yang sebelumnya telah ditandai sebagai agen yang merupakan ancaman kesehatan masyarakat yang besar (Rothan \& Byrareddy, 2020).

Pemberitaan Covid-19 sangatlah ramai di salah satu media social, seperti : Twitter merupakan salah satu media sosial yang ada dan digemari oleh para penggunanya, pengguna twitter dapat dengan bebas berpendapat, maupun sharing berbagai macam hal.

Situs microblogging kaya akan sumber untuk berbagai jenis informasi. Ini adalah tempat yang biasa di mana orang bertukar pendapat tentang berbagai masalah yang mungkin terjadi pada tren yang sedang berlangsung. Berdasarkan pengalaman mereka, mereka berbagi komentar atau keluhan pada produk apa pun dan mengekspresikan pemikiran mereka dalam hal sentimen positif atau negatif. Banyak organisasi yang akan datang memerlukan analisis umpan balik pada produk mereka untuk meningkatkan lebih lanjut. Sebagian besar waktu, Penyelenggara menganalisis tanggapan pengguna dan menjawabnya kembali di media sosial. Jadi, inilah tantangan untuk menganalisis atau mendeteksi dan menyelesaikan sentimen global (Trupthi et al., 2017).

Twitter adalah microblogging yang banyak digunakan platform dan layanan jejaring sosial yang menghasilkan luas jumlah informasi (Saad \& Yang, 2019). Dalam beberapa tahun terakhir, para peneliti lebih menyukai untuk memanfaatkan data sosial agar dapat digunakan untuk sentimen analisis pendapat orang tentang suatu produk, topik, atau peristiwa. Sentimen analisis, juga dikenal sebagai penambangan opini, merupakan proses bahasa alami yang penting tugas. Proses ini menentukan orientasi sentimen teks sebagai positif, negatif, atau netral (Kim \& Hovy, 2004; Whitelaw et al., 2005). Penambangan teks umumnya mencakup kategorisasi informasi atau teks, pengelompokan teks, ekstraksi entitas atau konsep, pengembangan dan perumusan taksonomi umum (Hashimi et al., 2015).

Sentimen analisis, juga disebut penambangan opini, adalah bidang studi yang menganalisis opini, sentimen, evaluasi, penilaian, sikap, dan emosi orang terhadap entitas seperti produk, layanan, organisasi, individu, masalah, peristiwa, topik, dan atributnya. Ini mewakili ruang masalah yang besar. Ada juga banyak nama dan tugas yang sedikit berbeda, mis., Analisis sentimen, penambangan opini, ekstraksi opini, penambangan sentimen, analisis subjektivitas, analisis pengaruh, analisis emosi, tinjauan penambangan, dll (Liu, 2012).
Pada sentimen analisis kali ini menggunakan algoritma klasifikasi yang terdiri dari Naive Bayes (NB), Support Vector Machine (SVM), dan $k$ Nearest Neighbor (k-NN) karena banyak dari penelitian-penelitian sebelumnya yang menggunakan algoritma tersebut. Ketiga algoritma tersebut digunakan untuk nantinya sebagai suatu metode klasifikasi yang dapat digunakan untuk memprediksi sentimen analis pada yang ada di dalam twitter terkait dengan stay home.

Pada penelitian sebelumnya yang pernah dilakukan berkaitan dengan masalah yang dihadapi penulis dimana dengan judul "Eksperimen Sistem Klasifikasi Analisa Sentimen Twitter pada Akun Resmi Pemerintahan Kota Surabaya Berbasis Pembelajaran Mesin". penelitian dilakukan oleh Faradhillah, Nuke Y. A..,dkk pada tahun 2016. Pada penelitian tersebut menggunakan 2 metode algoritma yang digunakan pada tahap klasifikasi yaitu Naive Bayes dan Support Vector Machine (SVM) didapatkan hasil bahwa nilai akurasi yang lebih tinggi dihasilkan dengan metode Support Vector Machine (SVM). Untuk perbandingan penggunaan kernel yaitu linear dan RBF, kernel RBF mempunyai hasil yang lebih bagus. Untuk nilai $C$ dan $\gamma$ terbaik yaitu $C=20$ dan $\gamma=2-1,25$ (Faradhillah et al., 2016).

Penelitian lainnya adalah "Analisis Sentimen Twitter Menggunakan Text Mining dengan Algoritma Naive Bayes Classifier". Penelitian dilakukan oleh Sudiantoro, Adhi V..,dkk pada tahun 2018. Penelitian ini menghasilkan Algoritma Naive Bayes Classifier sangat efektif untuk digunakan sebagai proses klasifikasi tweets yang dibutuhkan dalam sistem sentimen analisis ini dimana nilai yang di dapatkan dalam pengujian sampai $84 \%$. Metode Naive Bayes Classifier dapat digunakan untuk melakukan klasifikasi tweets dengan cukup baik pada sistem sentimen analisis. 300 data yang dibagi menjadi 2 yaitu data latih sebanyak 200 data dan data uji berjumlah 100 data. Hasil dari klasifikasi diketahui bahwa 100 data yang diuji masuk dalam kategori sentimen negatif (Sudiantoro et al., 2018).

\section{METODOLOGI PENELITIAN}

\section{Tahap Pengumpulan Data}

Pada proses awal pengumpulan data, menggunakan twitterscrapper yang tersedia pada anaconda promt. Dengan menggunakan aplikasi tersebut proses penarikan data tweets pada twitter dapat dilakukan. Adapun tahapan dalam melakukan proses tersebut dapat dilihat pada Gambar 1 . 


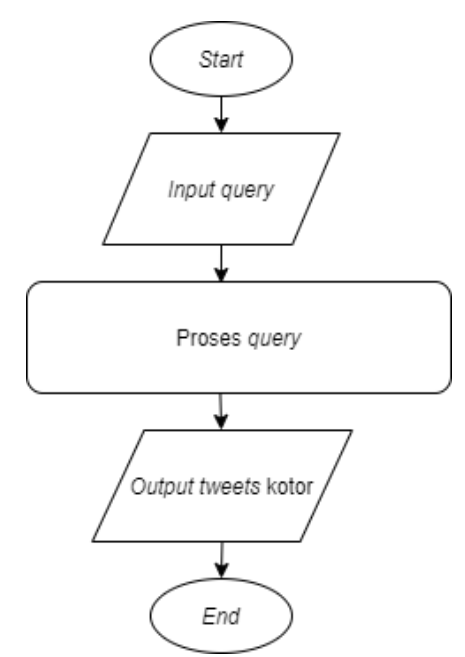

Gambar 1. Tahap Pengumpulan Data

Dari Gambar 1 dapat dilihat jika hasil akhir dari tahap pengumpulan data untuk mendapatkan tweets yang berkaitan dengan stay home yang untuk selanjutnya dapat digunakan di tahap preprossesing.

\section{Tahap Preposessing}

Proses preposessing ini dilakukan melalui beberapa proses agar dapat menghasilkan data tweets yang baik, yang nantinya akan digunakan pada proses pengolahan data. Proses tersebut dilakukan karena pada proses pengumpulan data tweets, masih didapati tweets yang kurang sempurna. Seperti masih adanya simbol, url, dan beberapa data lain yang harus dilakukan pernyempurnaan agar mendapatkan hasil yang maksimal. Adapun tahapan dalam melakukan preposessing ini adalah :

\section{a. Regex Removal}

Pada tahap ini akan dilakukan proses pembersihan kata-kata didalam tweets yang masih terdapat simbol-simbol, seperti (!'”, , ' dst).

Contoh : We're "extreme distancing" because no one knows who may have it

Menjadi : Were extreme distancing because no one knows who may have it

\section{b. Remove URL}

Pada tahap ini akan dilakukan proses pembersihan url yang masih ada didalam tweets, seperti (http, .com, dst).

Contoh : ones flying. https://www.wsj.com

Menjadi : ones flying

\section{c. Remove Annotation}

Pada tahap ini akan dilakukan proses pembersihan tweets yang masih mengandung username '@' didalamnya.
Contoh : @TIMOTHY45231830 Stay home stay safe stay healthy

Menjadi : Stay home stay safe stay healthy

\section{d. Remove Duplicate Tweets}

Pada tahap ini tweets yang memiliki isi yang sama akan dihapus, hal tersebut dilakukan untuk menghindari duplikasi isi dari tweets yang sudah ada sebelumnya agar dapat meningkatkan hasil akurasi.

\section{e. Extract Sentiment}

Pada tahap ini menggunakan model vader, proses tersebut dilakukan untuk mengolah data agar tiap tweets mendapatkan label sesuai dengan value masing-masing.

\section{f. Transform Case}

Pada tahap ini semua huruf yang ada didalam tweets menjadi huruf kecil. Hanya huruf "a" sampai dengan " $z$ " yang akan dilakukan perubahan.

Contoh : Were extreme distancing because no one knows who may have it

Menjadi : were extreme distancing because no one knows who may have it

Berikut adalah flowchart dari tahapan preprocessing berlangsung yang dapat dilihat di Gambar 2.

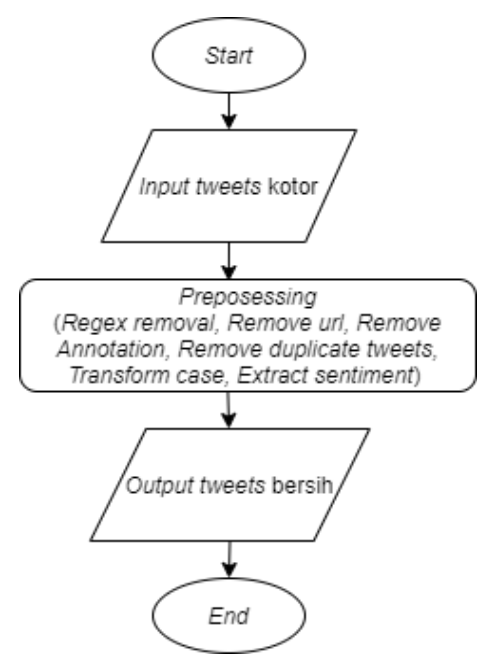

Gambar 2. Tahapan Preprocessing

Dari Gambar 2 dapat dilihat jika hasil akhir dari tahap preprocessing untuk mendapatkan tweets bersih yang sudah dapat digunakan. 


\section{Tahap Pengujian Data}

Tahapan ini dibuat agar dapat menggambarkan tahapan-tahapan dari proses yang dilakukan aplikasi sentimen analisis mulai dari pengambilan data, preprosessing, perhitungan klasifikasi sampai dengan akurasi.

Data yang digunakan adalah data tweets bersih hasil dari tahapan preprocessing sebelumnya yang akan dilakukan uji coba, dengan menggunakan tiga perhitungan algoritma yang terdiri dari Naive Bayes $(N B)$, Support Vector Machine (SVM), dan $k$-Nearest Neighbor $(k-N N)$.

Dengan menambahkan operator toolbox SMOTE Upsampling, penggunaan proses tersebut dilakukan agar data tweets menjadi lebih seimbang antara tweets yang berlabel positive maupun negative. Sehingga dengan melalui tahapan tersebut dapat meningkatkan hasil akurasi pada percobaan data tweets. Flowchart bagaimana tahap pengujian data dapat dilihat di Gambar 3.

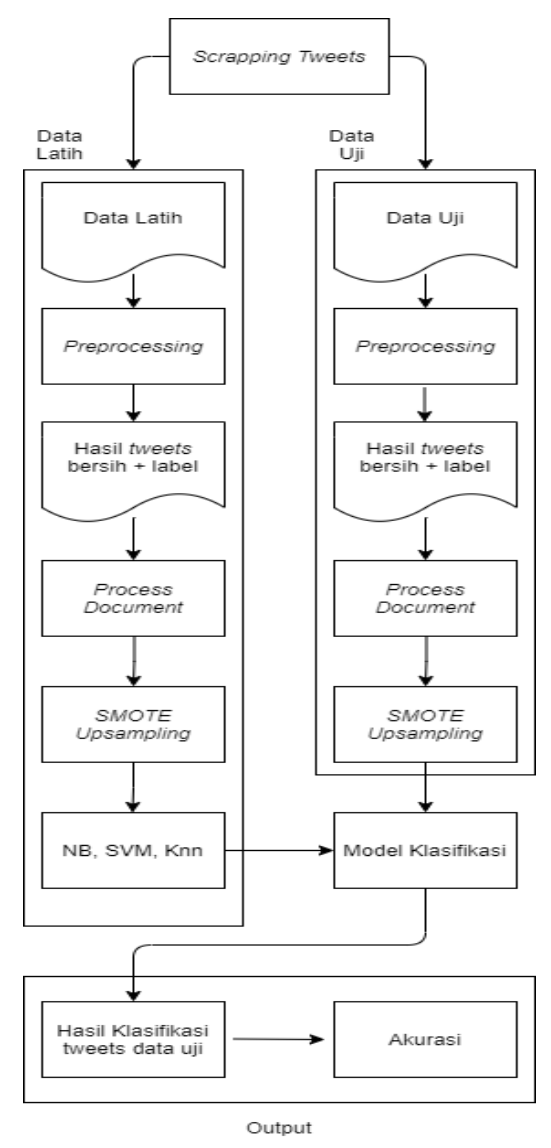

Gambar 3. Proses Tahap Pengujian Data

Dari Gambar 3 dapat dilihat output dari sistem yang dibuat berupa 2 kategori (positive, dan negative). Hasil yang dapat diperoleh dari sistem terhadap data tweets yang diuji, akan mendapatkan tingkat akurasi dari tiap algoritma berbeda yang akan bentuk tersaji dalam bentuk presentase.

\section{HASIL DAN PEMBAHASAN}

\section{Scrapping Tweets}

Pengambilan tweets menggunakan twitterscrapper pada anaconda promt, data tweets diambil dari tanggal 1 Maret 2020 - 1 April 2020. Jumlah data yang terkumpul dalam kurun waktu tersebut sebanyak 1652 tweets berhasil dikumpulkan dan berikut adalah hasil dari 10 tweets yang terambil.

Tabel 1. Hasil Scrapping Twitter

\begin{tabular}{ll}
\hline No & Tweets \\
\hline 1 & We're "extreme distancing" because no one knows \\
2 & Interesting the advertisement under your post \\
3 & Following directives? The @ CDCgov said to stay \\
4 & Please suspend work and bills for 14 days let our \\
5 & Yes, Dr said stay home 14 days \\
6 & Stop listening to the evil people...they will always \\
& try.. \\
7 & These knuckle heads can't even keep out streets,publ \\
8 & It is great time to prepare. Stay home \& read \\
9 & I've been thinking that this is what we should \\
10 & You need to pay us to stay home, period \\
\hline
\end{tabular}

Dari Tabel 1 kita dapat melihat bahwa data tweets kotor yang terkumpul, dimana masih banyak data yang kurang sempurna. Tentu saja data tersebut belum dapat digunakan untuk diuji.

\section{Preprocessing}

Setelah memperoleh data tweets kotor dari hasil scrapping twitter, maka tahapan selanjutnya adalah preprocessing. Melalui tahapan ini tweets kotor diolah melalui berbagai macam proses seperti : Regex Removal, Remove URL, Remove Annotation, Remove Duplicate Tweets, Extract Sentiment, Transform Case. Tahapan selanjutnya adalah proses preprocessing, target dari proses ini sendiri akan menghasilkan tweets bersih. Berikut adalah hasil dari 10 tweets yang sudah dilakukan tahap preprocessing.

Tabel 2. Hasil Preprocessing

\begin{tabular}{ll}
\hline No & Tweets \\
\hline 1 & were extreme distancing because no one knows \\
2 & interesting the advertisement under your post \\
3 & following directives the said to stay \\
4 & please suspend work and bills for 14 days let our \\
5 & yes dr said stay home 14 days \\
6 & stop listening to the evil peoplethey will always try \\
7 & these knuckle heads cant even keep out streetpubl \\
8 & if it makes me a stay home mom im down \\
9 & it is great time to prepare stay home read \\
10 & stay home cuzao \\
\hline
\end{tabular}

Dari Tabel 2 setelah melalui tahap preprocessing dapat dilihat perubahan data tweets, data sudah menjadi lebih baik, sudah tidak lagi terdapat simbol, tanda baca, dll. 
Berikut adalah contoh hasil dari tweets yang sudah dilakukan pelabelan menggunakan vader, yang dapat dilihat di Tabel 3.

\section{Tabel 3. Hasil Vader}

\begin{tabular}{|c|c|c|c|}
\hline No & Tweets & Nilai & Status \\
\hline 1 & $\begin{array}{l}\text { were extreme } \\
\text { distancing because no } \\
\text { one knows }\end{array}$ & $-0,025$ & Negative \\
\hline 2 & $\begin{array}{l}\text { interesting } \\
\text { advertisement } \\
\text { yourpost }\end{array}$ & 2,384 & Positive \\
\hline 3 & $\begin{array}{l}\text { following directives the } \\
\text { said to stay }\end{array}$ & $-0,948$ & Negative \\
\hline 4 & $\begin{array}{l}\text { please suspend work } \\
\text { and bills for } 14 \text { days let } \\
\text { our }\end{array}$ & $-0,307$ & Negative \\
\hline 5 & $\begin{array}{l}\text { yes dr said stay home } \\
14 \text { days }\end{array}$ & 0,435 & Positive \\
\hline 6 & $\begin{array}{l}\text { stop listening to the evil } \\
\text { peoplethey will always } \\
\text { try }\end{array}$ & $-0,692$ & Negative \\
\hline 7 & $\begin{array}{l}\text { these knuckle heads } \\
\text { cant even keep out } \\
\text { streetpubl }\end{array}$ & 0,179 & Positive \\
\hline 8 & I pharma screwed us & $-0,564$ & Negative \\
\hline 9 & $\begin{array}{l}\text { it is great time to } \\
\text { prepare stay home read }\end{array}$ & 0,794 & Positive \\
\hline 10 & $\begin{array}{l}\text { you need to pay us to } \\
\text { stay home period }\end{array}$ & 0,461 & Positive \\
\hline
\end{tabular}

Seperti yang diketahui bersama berdasarkan dari Tabel 3 diatas, diperoleh nilai dari tiap tweets yang seluruh prosesnya menggunakan bantuan dari vader. Jika sudah mendapatkan data tersebut maka data sudah dapat digunakan untuk proses selanjutnya yaitu proses pengujian data.

\section{Pengujian Data}

Pada tahapan ini, data tweets hasil dari preprocessing akan diolah dengan menggunakan tiga algoritma yang terdiri dari Naive Bayes (NB), Support Vector Machine (SVM), dan k-Nearest Neighbor ( $k-N N)$.

\section{a. Naive Bayes}

Berikut ini adalah hasil pengolahan data yang sudah diproses menggunakan algortima naive bayes, yang dapat dilihat pada Tabel 4.

Tabel 4. Hasil dari $N B+$ SMOTE

\begin{tabular}{lccc}
\hline & $\begin{array}{c}\text { True } \\
\text { Negative }\end{array}$ & $\begin{array}{c}\text { True } \\
\text { Positive }\end{array}$ & $\begin{array}{c}\text { Class } \\
\text { precision }\end{array}$ \\
\hline $\begin{array}{l}\text { Pred. } \\
\text { Negative }\end{array}$ & 466 & 268 & $63,49 \%$ \\
$\begin{array}{l}\text { Pred. } \\
\text { Positive }\end{array}$ & 123 & 321 & $72,30 \%$ \\
$\begin{array}{l}\text { Class } \\
\text { Recall }\end{array}$ & $79,12 \%$ & $54.50 \%$ & \\
\hline
\end{tabular}

Sedangkan untuk hasil dari akurasi menggunakan naive bayes + SMOTE sebesar $66,81 \%$

\section{b. Support Vector Machine}

Berikut ini adalah hasil pengolahan data yang sudah diproses menggunakan algortima support vector machine, yang dapat dilihat pada Tabel 5.

Tabel 5. Hasil dari SVM + SMOTE

\begin{tabular}{lccc}
\hline & $\begin{array}{c}\text { True } \\
\text { Negative }\end{array}$ & $\begin{array}{c}\text { True } \\
\text { Positive }\end{array}$ & $\begin{array}{c}\text { Class } \\
\text { precision }\end{array}$ \\
\hline $\begin{array}{l}\text { Pred. } \\
\text { Negative }\end{array}$ & 452 & 82 & $82,18 \%$ \\
$\begin{array}{l}\text { Pred. } \\
\text { Positive }\end{array}$ & 137 & 491 & $78,18 \%$ \\
$\begin{array}{l}\text { Class } \\
\text { Recall }\end{array}$ & $76,74 \%$ & $83,36 \%$ & \\
\hline
\end{tabular}

Sedangkan untuk hasil dari akurasi menggunakan support vector machine + SMOTE sebesar $80,05 \%$

\section{c. $k$-Nearest Neighbor}

Berikut ini adalah hasil pengolahan data yang sudah diproses menggunakan algortima $k$-Nearest Neighbor, yang dapat dilihat pada Tabel 6.

Tabel 6. Hasil dari $k-N N+S M O T E$

\begin{tabular}{lccc}
\hline & $\begin{array}{l}\text { True } \\
\text { Negative }\end{array}$ & $\begin{array}{l}\text { True } \\
\text { Positive }\end{array}$ & $\begin{array}{l}\text { Class } \\
\text { precision }\end{array}$ \\
\hline $\begin{array}{l}\text { Pred. } \\
\text { Negative }\end{array}$ & 589 & 572 & $50,73 \%$ \\
$\begin{array}{l}\text { Pred. } \\
\text { Positive }\end{array}$ & 0 & 17 & $100 \%$ \\
$\begin{array}{l}\text { Class } \\
\text { Recall }\end{array}$ & $100 \%$ & $2,89 \%$ & \\
\hline
\end{tabular}

Sedangkan untuk hasil dari akurasi menggunakan $k$ Nearest Neighbor + SMOTE sebesar 51,45\%

Berikut adalah hasil rekapitulasi dari ketiga algoritma, setelah proses pengujian data dilakukan dan didapati hasil akurasi yang berbeda-beda. Data tersebut dapat dilihat pada Tabel 7.

Tabel 7. Hasil Rekapitulasi Akurasi

\begin{tabular}{lc}
\hline & Akurasi \\
\hline NB + & $66,81 \%$ \\
SMOTE & \\
SVM + & $80,05 \%$ \\
SMOTE & \\
k-NN + & $51,45 \%$ \\
SMOTE & \\
\hline
\end{tabular}




\section{KESIMPULAN}

Setelah melalui proses panjang dari pengumpulan data sampai dengan pengujian data. Ketiga algoritma yang digunakan mendapatkan hasil akurasi yang berbeda-beda. Hasil terbaik didapatkan dengan menggunakan support vector machine mengungguli kedua algoritma yang lain dengan mendapatkan akurasi sebesar $80,05 \%$. Sangat besar kemungkinan hasil dari akurasi dapat meningkat apabila dilakukan beberapa optimalisasi ataupun dengan metode yang berbeda terkait dengan pengujian data diatas.

\section{REFERENSI}

Faradhillah, N. Y. A., Kusumawardani, R. P., Hafidz, I., Informasi, J. S., \& Informasi, F. T. (2016). Eksperimen Sistem Klasifikasi Analisa Sentimen Twitter pada Akun Resmi Pemerintahan Kota Surabaya Berbasis Pembelajaran Mesin.

Hashimi, H., Hafez, A., \& Mathkour, H. (2015). Selection criteria for text mining approaches. Computers in Human Behavior, 51, 729-733. https://doi.org/10.1016/j.chb.2014.10.062

Kim, S.-M., \& Hovy, E. (2004). Determining the sentiment of opinions. 1367-es. https://doi.org/10.3115/1220355.1220555

Liu, B. (2012). Opinion spam detection. In Sentiment Analysis and Opinion Mining (Issue April). https://doi.org/10.1142/9789813100459_0007

Lu, H., Stratton, C. W., \& Tang, Y. W. (2020). Outbreak of pneumonia of unknown etiology in Wuhan, China: The mystery and the miracle. Journal of Medical Virology, 92(4), 401-402. https://doi.org/10.1002/jmv.25678

Rothan, H. A., \& Byrareddy, S. N. (2020). The epidemiology and pathogenesis of coronavirus disease (COVID-19) outbreak. Journal of Autoimmunity, February, 102433. https://doi.org/10.1016/j.jaut.2020.102433

Saad, S. E., \& Yang, J. (2019). Twitter Sentiment Analysis Based on Ordinal Regression. IEEE Access, 7, 163677-163685. https://doi.org/10.1109/ACCESS.2019.295212
7

Sudiantoro, A. V., Zuliarso, E., Studi, P., Informatika, T., Informasi, F. T., Stikubank, U., \& Mining, T. (2018). Analisis Sentimen Twitter Menggunakan Text Mining dengan Algoritma Naive Bayes Classifier. 398-401.

Trupthi, M., Pabboju, S., \& Narasimha, G. (2017). Sentiment analysis on twitter using streaming API. Proceedings - 7th IEEE International Advanced Computing Conference, IACC 2017, 915-919. https://doi.org/10.1109/IACC.2017.0186

Whitelaw, C., Garg, N., \& Argamon, S. (2005). Using appraisal groups for sentiment analysis. International Conference on Information and Knowledge Management, Proceedings, 625631. https://doi.org/10.1145/1099554.1099714

\section{PROFIL PENULIS}

Ikhwanul Hakim, B.Ict

Mahasiswa Program Studi Magister Ilmu Komputer, Fakultas Ilmu Komputer, STMIK Nusa Mandiri. Jl. Kramat Raya No.18, RT.5/RW.7, Kwitang, Kec. Senen, Kota Jakarta Pusat, Daerah Khusus Ibukota Jakarta 10450.

Arifin Nugroho, S.Kom

Mahasiswa Program Studi Magister Ilmu Komputer, Fakultas Ilmu Komputer, STMIK Nusa Mandiri. J1. Kramat Raya No.18, RT.5/RW.7, Kwitang, Kec. Senen, Kota Jakarta Pusat, Daerah Khusus Ibukota Jakarta 10450.

Sulaeman Hadi Sukmana, M.Kom

Dosen STMIK Nusa Mandiri. Jl. Kramat Raya No.18, RT.5/RW.7, Kwitang, Kec. Senen, Kota Jakarta Pusat, Daerah Khusus Ibukota Jakarta 10450 .

Dr. Windu Gata, M.Kom

Dosen STMIK Nusa Mandiri. Jl. Kramat Raya No.18, RT.5/RW.7, Kwitang, Kec. Senen, Kota Jakarta Pusat, Daerah Khusus Ibukota Jakarta 10450 . 